\title{
Can the institution speak? The university as testimony in Canada today
}

\author{
LEN M. FINDLAY
}

This article has two parts, each exploring the possibility and effectiveness of testimony. In the first part, I take up Gayatri Spivak's endlessly exacting question, 'Can the subaltern speak ' $^{1}$ The essay so entitled connects testimony to postcolonial studies and to the politics of voice and script inside and outside the 'semiotic stockade' ${ }^{2}$ - a place of meaning making where the colonised other is and was so often confined but could always, at least somatically, remain resistant because inassimilable. In the second part-and stimulated especially by Spivak's considerations of institutional and disciplinary politics - I offer an assessment of the current capacity of Canadian universities to nurture and legitimate testimony. Here I will use the proposal to boycott Israeli universities - a proposal considered and then rejected by the professoriate in the United Kingdom - to illustrate some of the limits to testimony within institutions ostensibly dedicated to that very activity.

\section{Can the subaltern speak (yet)?}

When it appeared in 1988, in a collection featuring some of the most eminent cultural theorists working in English, Gayatri Spivak's long, dense, brilliantly contrarian essay gave testimony about testimony. She posed a question that seemed to many readers to have a self-evident answer and therefore to be a rhetorical question appealing confidently to a pre-existing consensus on a particular matter. The answer to her question seemed to go something like this: 'Of course, the subaltern can speak, even though no-one may be listening.' As she de-naturalises this deceptively simple question in a welter of complex preliminaries, one comes to realise that Spivak's critical attention has expanded

\footnotetext{
1 Spivak, Gayatri Chakravorty 1988, 'Can the subaltern speak?', in Cary Nelson and Lawrence Grossberg (eds), Marxism and the Interpretation of Culture, University of Illinois Press, Urbana.

2 Findlay, L. M. 2004, 'Print culture and decolonizing the university: indigenizing the page', in Peter Stoicheff and Andrew Taylor (eds), The Future of the Page, University of Toronto Press, Toronto, p. 129.
} 
from a report on the receptivity of the dominant as listeners to a meditation on the category of the subaltern as such. For Spivak, this latter subject position will silence anyone entitled to occupy it, even when their identity is not reducible or confinable to subalternity itself. Accordingly, no subaltern qua subaltern can speak. In proffering a question as the primary product or outcome of intense and wide-ranging deliberation, Spivak opens up to interrogation the First World, its reluctantly embedded academics and their host institutions as being committed to coyly self-interested answers pursued under the aegis of disinterestedness and objectivity. In attesting to the complexities of testimony, this implacable postcolonial scholar suggests to her peers that academic speech and writing might be more problematic than the subaltern's silence.

As hinted at above, however, a question can also be an answer. A rhetorical question aims to silence pre-emptively those who might otherwise be disposed to respond to it. Spivak's theoretical and logical strategies usually entail at least a double gesture and raise the prospect of aporia rather than ready consensus. Accordingly, her question is unconfinable to the condition of not requiring an answer. Instead, she reclaims it for the self-evident's polar opposite-namely, unanswerability - and this binary arrangement is then complicated by the answering of the unanswerable in inconvenient ways, ways meticulously contextual and attentive to the social relations of exchange and its endlessly asymmetrical outcomes. The epideictic morphs into its other, the inscrutable enigma, and in so doing opens space for further reflection. As a result, there is no answer to the question because there is no-one in a position to answer it; but there are also several versions of the wrong answer designed to leave Spivak's primary audience of Euro-American radical scholars unsettled and defensive. The doubleness of Spivak's no/yes gesture combines with the doubleness of the 'session of representations'3 she mentions, and the role of proper names in processes of grammatical abduction, catachresis and mistranslation, to underwrite her provocative alignment with Derrida, who remained in 1988 the most ostensibly apolitical of high theorists. ${ }^{4}$ This Derridean alignment, ironically enough, adds spine and bite to Spivak's exposure of the self-serving inscriptions perpetuated by the proponents of discourse analysis in the name of emancipative critique. The academic vanguard gets its comeuppance from an authority who is both in concert and at variance with that vanguard's selfcongratulatory 'radical practice'.

By the end of the first section of her four-part essay, Spivak has identified as sites of unfinished critical business the intellectual and his institution. Both

3 Spivak, 'Can the subaltern speak?', p. 279.

4 See Cheah, Pheng and Guerlac, Suzanne 2009, 'Introduction', in Pheng Cheah and Suzanne Guerlac (eds), Derrida and the Time of the Political, Duke University Press, Durham and London, pp. 1-37.

5 'Can the subaltern speak?', p. 279. 
purvey fictions of transparency while functioning as sources of co-opted decolonisation. This account of complicitous scholarship opens onto the essay's second section, in which epistemic violence is exposed as 'remotely orchestrated'. ${ }^{6}$ Spivak counters this disingenuous detachment by insisting on physical proximity to the subaltern as a precondition for even speaking for or of her non-coercively. Testimony, in its wary intimacy and vulnerable oneness, speaks to the scandalous homogeneity of the human, the very possibility of which - outside sentimental and paternalistic versions of it - offers hope of discursive justice that might tie testimony, beyond efforts at recognition and advocacy, to redress and redistribution. In advancing this claim, Spivak resorts to self-consciously 'schematic summary" ${ }^{7}$ and to the interpretation of the colonial archive in India with the same rigour that she has already brought to bear on Foucault and Deleuze. Hence, when we first encounter within the text the question that gives her essay its title, it is already thoroughly embedded in colonialism. This arrangement allows for radical notions of the collective to be 'persistently foreclosed ${ }^{8}$ by vanguard manipulations of the collective feminine. In the Indian context, Spivak redeems the monolith of 'the people' from the long-distance simplifications of post-colonialists and neo-colonisers, but also from the homogenising of the underclass by Ranajit Guha and the Subaltern Studies group. In differentiating the native Indian intellectual predicament from the First World one, however, Spivak lets neither world off the hook. Ideology connects to testimony ${ }^{9}$ in ways that require reading for silences and contradictions. Gendering the subaltern creates gradations of silence and obscurity. Meanwhile, at the heart of this racialised masculinity is 'the' university - an institution that remains crypto-imperialistic even in its most progressive national settings and faculties. It is an institution that speaks only with forked tongue, and while subjecting subalterns to elision or disfigurement.

The next short section of the essay shifts back to the dominant in the form of Derrida so as to theorise more fully the category of speech and the problematic presence of the speaking subject to herself and others. Only now are we ready for the concerted coming into possibility of the essay's key question and its re-problematising answers. Here, the notorious practice of sati is engaged with in an estranging philological analysis and guarded affirmation of Hindu communalism's gendered asymmetries. In the course of Spivak's careful reading there are abundant challenges for even the best-intentioned outsider, as when she takes on E. P. Thompson's father's attempt to violate and dismiss the interiority of the Hindu widow, the allure and unruliness of her affect: 
A look at the pathetically misspelled names of the satis of the artisanal, peasant, village-priestly, moneylender, clerical, and comparable social groups in Bengal, where satis were most common, would not have yielded such a harvest... Or perhaps it would. There is no more dangerous pastime than transposing proper names into common nouns, translating them, and using them as sociological evidence. I attempted to reconstruct the names on that list and began to feel Hervey-Thompson's arrogance. What, for instance, might 'Comfort' have been? Was it 'Shanti'? Readers are reminded of the last line of T.S. Eliot's Wasteland. There the word bears the mark of one kind of stereotyping of Indiathe grandeur of the ecumenical Upanishads. Or was it 'Swasti'? Readers are reminded of the swastika, the Brahmanic ritual mark of domestic comfort (as in 'God Bless Our Home') stereotyped into a criminal parody of Aryan hegemony. Between these two appropriations, where is our pretty and constant burnt widow? The aura of the names owes more to writers like Edward Fitzgerald, the 'translator' of the Rubayyat of Omar Khayyam who helped to construct a certain picture of the Oriental woman through the supposed 'objectivity' of translation, than to sociological exactitude. (Said's Orientalism, 1978, remains the authoritative text here.) By this sort of reckoning, the translated proper names of a random collection of contemporary French philosophers or boards of directors of prestigious southern U.S. corporations would give evidence of a ferocious investment in an archangelic and hagiocentric theocracy. Such sleights of pen can be perpetuated on 'common nouns' as well, but the proper name is most susceptible to the trick. And it is the British trick with sati that we are discussing. After such a taming of the subject Thompson can write, under the heading 'The Psychology of the "Sati"' "I had intended to try to examine this; but the truth is, it has ceased to seem a puzzle to me.' ${ }^{\prime 10}$

The imperial expert experiences Spivak's native India, like this Indian affect, as transcribable and mappable. The determination to name and master empirical or affective otherness, however benevolent its impulse, performs a desire thwarted by the excessive and intractable 'deficiencies' of the other. Spivak reveals a mis-transcription masquerading as translation, a mistaken inventory ignorant of the 'hidden transcript' ${ }^{\prime 1}$ of Indian resistance while ushering in the civilised proscription of widow burning. The rigours of selectively comparative philology are employed to conjure an absent original out of the appropriative pages of imperial expertise; meanwhile, the subversive supplementation of

10 Ibid., p. 306.

11 Scott, James C. 1990, Domination and the Arts of Resistance: Hidden transcripts, Yale University Press, New Haven. 
deconstruction allows Spivak to mount an offensive against 'perfect' exemplars of colonial presumption while also revealing the unidirectional nature of their patronising onomastics.

Spivak, after arguing for the residual unreadability of subaltern names by the colonial expert, underscores the implications of European appropriation with damning force:

Between patriarchy and imperialism, subject-constitution and objectformation, the figure of the woman disappears, not into a pristine nothingness, but into a violent shuttling which is the displaced figuration of the 'third-world woman' caught between tradition and modernization. These considerations would revise every detail of judgements [like Foucault's] that seem valid for a history of sexuality in the West: 'Such would be the property of repression, that which distinguishes it from the prohibition maintained by simple penal law: repression functions well as a sentence [condamnation] to disappear, but also as an injunction to silence, affirmation of non-existence; and consequently states that of all of this there is nothing to say, to see, to know.' The case of suttee as exemplum of the woman-in-imperialism would challenge and deconstruct this opposition between subject (law) and object-of-knowledge (repression) and mark the place of 'disappearance' with something other than silence and non-existence, a violent aporia, between subject and object status. ${ }^{12}$

The intimidating density of this passage demands especially careful reading, as Spivak follows Said in seeing the East in the West in ways more unsettling than subservient, while she follows Derrida in seeing a politics of the undecidable where Foucault locates decisive processes of external and internal censorship. Foucault is cited, allowed to speak in his own (textualised) voice as distinguishing between legal prohibition and the repression that causes something to disappear. This is a 'sentence' meted out in no formal court or repressive state apparatus but in a triple injunction to be invisible, mute and effectively nonexistent. In this fashion, repressed sexuality is condemned to a black hole. Sati, however, shifts with Spivak's assistance from being a fixture on the margin to effectively undoing the text of Western sexuality. The institutional location of subject formation - in this case, in the law-cannot be separated from the psychological instruments of self-repression in the way Foucault proposes. For Spivak, the sanctions of the law consort with the sanctuaries of the psyche in dalliance without a duenna, and enforced absence testifies, albeit inadvertently, to a presence in the guise of a violent undecideability.

12 Spivak, 'Can the subaltern speak?', p. 306; Foucault's French term added (Foucault, Michel 1976, Historie de la Sexualité I. La volonté de savoir, Gallimard, Paris). 
So, apparent absence becomes an aporia understood as a signifier of power not powerlessness - indeed of power held in reserve beyond the discursive reach of the letter of the law and the disciplined psyche's still-small voice. This aporia claims the subaltern interstice for process beyond fixity and refuses the binary of outside/inside as it does so. From the bleakest of situations, the possibility of recuperatory resistance appears, but what form can it possibly take beyond an effect of abstrusely theorised language? How can human flesh and blood and agency be restored to that which has been figured in turn as 'displacement', 'violent shuttling' and 'violent aporia', as if readable only as a matter/energy notation in the scopes and scripts of subatomic physics?

Spivak has an answer to this question - a historically grounded and strategically brilliant one. After reaffirming via the mythic provenance of sati that there is no space for the sexed subaltern to speak', ${ }^{13}$ Spivak brings back from India's prodigious archive the figure of the menstruating suicide. It is a memorable, even shocking moment, which in its economy outdoes the painstaking reclamation of marginal figures by Foucault himself and the New Historicists he inspired.

A young woman of sixteen or seventeen, Bhuvaneswari Bhaduri, hanged herself in her father's modest apartment in North Calcutta in 1926. The suicide was a puzzle since, as Bhuvaneswari was menstruating at the time, it was clearly not a case of illicit pregnancy. Nearly a decade later, it was discovered that she was a member of one of the many groups involved in the armed struggle for Indian independence. She had finally been entrusted with a political assassination. Unable to confront the task and yet aware of the political need for trust, she killed herself.

Bhuvaneswari had known that her death would be diagnosed as the outcome of an illegitimate passion. She had therefore waited for the onset of menstruation. While waiting, Bhuvaneswari, the brahmacārini who was no doubt looking forward to good wifehood, perhaps rewrote the social text of sati-suicide in an interventionist way. (One tentative explanation of her inexplicable act had been a possible melancholia brought on by her brother-in-law's repeated taunts that she was too old to be not-yet-a-wife.) She generalized the sanctioned motive for female suicide by taking immense trouble to displace (not merely deny), in the physiological inscription of her body, its imprisonment within legitimate passion by a single male. In the immediate context, her act became absurd, a case of delirium rather than sanity. The displacing gesturewaiting for menstruation - is at first a reversal of the interdict against

13 Spivak, 'Can the subaltern speak?', p. 307. 
a menstruating widow's right to immolate herself; the unclean widow must wait, publicly, until the cleansing bath of the fourth day, when she is no longer menstruating, in order to claim her dubious privilege.

In this reading, Bhunasveri Bhaduri's suicide is an unemphatic, ad hoc, subaltern rewriting of the social text of sati-suicide as much as the hegemonic account of the blazing, fighting, familial Durga. The emergent dissenting possibilities of that hegemonic account of the fighting mother are well documented and popularly well remembered through the discourse of the male leaders and participants in the independence movement. The subaltern as female cannot be heard or read. ${ }^{14}$

This account is not offered as a 'model' for 'some violent Hindu sisterhood of self-destruction' but rather as an example drawn from the body of 'objects of discourse analysis for the non-self-abdicating intellectual'. ${ }^{15}$ This modest goal doubles as brazen ambition, for it is chosen to conclude the most emphatically ambitious essay in a collection with little time for self-effacement. Spivak's essay is not, however, confidently programmatic, except - as will become clearer in what succeeds it - in its alignment with Derridean deconstruction against the more directly political discursive practices of Foucault and Deleuze.

The example of Bhuvaneswari is presented in a style quite different from that of the two earlier extended citations from Spivak's essay. This last passage is not recondite theoretical discourse. It speaks straightforwardly to, rather than for, an exemplary subaltern whose act of self-silencing is carefully located in time and space. A lot is going on here, despite the relative plainness of the language. The suicide is a 'puzzle', according to Spivak, who reuses the very term that Thomson disavows in abandoning his interest in the 'psychology of the sati'. Bhuvaneswari's death is aligned with anti-colonial politics, within which a quandary about killing another human being leads to her own act of self-determination through self-erasure. She is an intelligibly embodied subject who wishes to avoid becoming a burden on the independence movement and a danger to her own insurgent group. She is a Hindu Hamlet, if you will, who prefers the 'bare bodkin' to an 'almost blunted purpose'. But how is she to testify to multiple and discrete audiences? In which court of opinion will she choose, if she can, to be tried? The account transforms confinement into capacity, but capacity without triumphalism precisely because the somatic domain has been used so often to confine and punish female agency. Bhuvaneswari's power lies in part in intellectual analysis of the interpretative practices of her society. Her power is also ethical, deriving from a principled refusal to kill. And her power is decisively somatic, enabled by her intimacy with cycles of her own body and

14 Ibid., pp. 307-8.

15 Ibid., p. 307. 
the fact that such complementary knowledge can help locate her death in the overlapping zones of testimony, mystery and conjecture while excluding the possibilities of romantic guilt or heartbreak.

This young freedom fighter chooses to die at home, and to be found and tended by her family. She is a young person moved in two apparently incompatible directions by the power of an idea-a political idea. She traumatises her intimates, who find her lifeless, clearly suicidal body hanging in that "modest apartment' and she subjects them to this horror so as to protect her political associates - affiliation thus trumping filiation, and all of this occurring within the imbricated matrices of tradition and modernity. She is a test case of the female disappearance of which Spivak writes earlier in her essay, an absence that shuttles violently between two poles, and she incarnates too the violence of the resultant aporia. Bhuvaneswari proves Spivak's theory of subaltern disappearance while also proving it by exceeding it. She cannot speak, yet she speaks figuratively in her life and from beyond the grave. She is silentpermanently. Yet her management of time and space and bodily placement speaks volumes, over time, for those who care to investigate and reflect on her passing. She 'self-abdicates' but not intellectually or ethically or somatically. She is named, but not as a prelude to presumptuous onomastics. Her name is not a name to conjure with, but - for some - to be forgotten in the wake of 'real' female accomplishment in her family. Spivak retrieves a 'voice' from quasioblivion through 'family connections' ${ }^{16}$ and against the grain of gossip and nativist shame where tradition and modernity are invested in professional selfadvancement rather than political martyrdom. In other words, both tradition and modernity accommodate a derivative bourgeois feminism, which is also not feminism in the Spivakian sense. Bhuvaneswari is misrepresented by her 'nieces', not rescued by radical theorists such as Foucault and Deleuze, who are unconsciously bent on 'appropriating the other through assimilation' ${ }^{17}$ The implacably self-subverting Derrida and the bracing non-identity of feminism and deconstruction are the sole sources of hope that Spivak's 'problematic' can be addressed at all, in a shifting, difficult space between colonial condescension and radical solidarity, the over-determined, voluble self-muting of Bhuvaneswari as politically charged, ethical agent.

This essay comes to (un)rest, finally, between two acts of allegiance: to the woman subaltern and the male deconstructionist, and to the discursive discipline that goes with a particular professional territory: "The subaltern cannot speak. There is no virtue in global laundry lists with "woman" as a pious item. Representation has not withered away. The female intellectual as intellectual has

16 Ibid., p. 308.

17 Ibid., p. 308. 
a circumscribed task which she must not disown with a flourish.' ${ }^{18}$ The 'female intellectual' must speak without bravado or presumption and from within the rigorous confines of responsible scholarship and teaching, responsible to the intellectual as such beyond the vagaries of righteous posturing and unthinking appropriation. In a typically dense and combative note to this passage, ${ }^{19}$ Spivak argues that chains of signification make possible regimes of representation that imprison the subaltern in malevolent and benevolent ways. The example can be exemplary only insofar as it refuses to purvey composite fictions such as 'third-world-woman' or endure reduction to an item in a 'laundry list'. And the preservation and promotion of this refusal, this apparent complicity with the silencing of the subaltern, are paradoxically but importantly intellectual work. A contrarian dissonance in the work of giving voice to those made silent by disadvantage and oppression leaves no-one feeling good because, while the gendered international division of labour continues unabated and in tandem with the First World plundering of the imperial archives of 'representation', no-one should feel good.

Bhuvaneswari was not to know how long it would take for India to achieve political independence. Moreover, neither she nor Spivak could know how much the figure of the suicidal female as suicide bomber would become in some quarters sati with a twist - the most potent signifier of female self-abasement within the patriarchal systems of the terrorist other so denominated in the 'civilised' West. Even as contexts change, however, Spivak's contrarian text and the sexed subaltern's defiant self-inscription still bear witness to testimony as a vexed and vexatious possibility in the shadow of avoidable enormity.

\section{Can the institution speak?}

We have seen how the subaltern's silence performs the blocking of testimony as speech and the facilitation of testimony in the conflicted idiom of embodiment. A subaltern female body is compliant but also a residually resistant site of displacement and counter-inscription of the social text of sati. Now let us test this communicative model a little more to see if it can add to our understanding of the nature and legitimacy of testimony. Let us try to change the power relations, flipping from subaltern to elite status, and from the withholding of full humanity from the sexed subaltern to the attribution of gender and generosity to the figure of the institution as alma mater studiorum - the 'nourishing mother' of masculine intellectual progeny at the University of Bologna and its many First World successors. Spivak sees universities, even in their most progressive

18 Ibid., p. 308.

19 Ibid., p. 313, n. 90. 
faculties, as sources of a problematic distance and of appropriating the voice of difference only to misrepresent it. But how do universities act on their own turf with their own people? What happens to their capacity to model and nourish unencumbered testimony when the university becomes the focus rather than simply the locus of inquiry?

From this self-scrutinising perspective can any institution of advanced education speak? The answer would seem to go something as follows: 'Of course it can, though never with one voice.' After all, 'the university' is a formula containing within itself a constitutive tension between sameness and diversity, the unitary and the multiple (and still multiplying) ways of organising knowledge. The distancing of the university in time and/or space from what it studies is often seen as a guarantor or strong signifier of democratic values, a source of its own robustness and of the political health of the society that houses it, through the provisions of institutional autonomy and academic freedom. Independent research and reflection, and the 'free and fearless' dissemination of their results, ${ }^{20}$ function then as loose synonyms for 'speaking truth to power' ${ }^{21}$ The integrity of this process helps promote the notion of the university as apolitical, despite the challenges of a dropout with a doctorate such as Karl Marx or a critical insider such as Henry Giroux, who dares to speak of the 'military industrial academic complex'.$^{22}$ Consequently, any ad hoc or systematic attempt to subvert the university as a safe place for the productive performance of difference, or even as a temple dedicated to the preservation, dissemination and eliciting of testimony, imperils some of the most cherished ideals of modern democratic states and their current commitment to a public culture of redress.

So what happens when a particular issue appears to galvanise institutions otherwise increasingly competitive with each other for market share of students, funding and repute, gathering rivals into quasi-unison so that they seem to speak internally and externally with one voice and as if of one mind? A threat to core values is thought to be the usual trigger for such a system-wide response. And one such trigger would seem to be the boycott of Israeli universities proposed in Britain in May 2007 by the University and College Union (UCU). ${ }^{23}$ When this proposal was made public there was a firestorm of controversy in many parts of the world. In Canada, for instance, there was a rush of responses that in their sequence and substance illustrated how readily Canada could take its cue from the United States. As a member of the Academic Freedom and Tenure

20 But see Findlay, L. M. and Bidwell, Paul (eds) 2001, Pursuing Academic Freedom: 'Free and fearless'?, Purich Publishing, Saskatoon.

21 But for the origin of this expression and its cautionary deployment in North America, see Findlay, L. M. 2000, "'Speaking truth to power"?: American usage, Canadian literary studies, and policies for the public good in Canada', English Studies in Canada,vol. 26, no. 3, pp. 279-307.

22 Giroux, Henry 2007, The University in Chains: Confronting the military-industrial-academic complex, Paradigm Publishers, Boulder, Colo.

23 For background, a substantial archive and regular updates, see the BRICUP web site. 
Committee of the Canadian Association of University Teachers (CAUT), I am regularly informed by association staff about international as well as domestic events that impact, or threaten to impact, the ability of Canadian academics and their colleagues elsewhere to exercise their academic freedom individually or in various formal or informal groupings. I was accordingly provided with testimonies from across Canada purporting to represent institutional positions vis-a-vis the boycott proposal not yet debated, far less ratified, by delegates to the first UCU annual assembly.

Throughout the 24 such statements I have studied, one finds evidence of hierarchy and a remarkable approximation to unanimity, a show of ethical internationalism and guild solidarity with sister institutions in Israel - a state both beleaguered and belligerent, hemmed in by enemies while also the recipient of carte blanche and massive military and financial assistance from the two-term Bush Administration in the United States whose most favoured proxy Israel became. As a consequence of the convergent exceptionalism of the Bush and Olmert administrations, and the unilateral and bilateral consequences of such convergence, the State of Israel acted in Lebanon, the West Bank and Gaza as one might expect. Ruthlessly self-interested and disproportionately punitive actions were undertaken by Israel, with effects that included the violation of academic freedom in Palestinian institutions. The relative lack of criticism within Israeli universities (the 407 academic signatories to a 2008 petition notwithstanding) ${ }^{24}$ and their deep entanglements with the military, surveillance and policy needs, and settlement expansion of their national security state, seemed to some to undermine academic solidarity in unforgivable ways. This was what the UCU proposal was designed to address, but it did not meet with favour in high places in North America where the 'Israeli lobby' seems most powerful. ${ }^{25}$ The situation is complex, the resultant chill and ethical challenges disturbing, but one is entitled to at least wonder and debate how the supposedly staunchest defenders of free speech and unencumbered inquiry - namely universities with their avowals of objectivity based on thorough research, can act in such remarkable concert. More specifically, how can one account for the pre-emptive speed and sameness of response from Canadian institutions to a proposal to consider discussing an optional reaction - a proposal aimed at institutions rather than individuals? Surely this results from the imperilling of a core value in an unequivocal way?

To be more pointed still, do free scholarly association and exchange trump all other considerations or is high-level concern about a possible boycott inconsistent and hypocritical, restricted to defending the 'free market' in

24 See Fisch, Menachem et al. n.d., Academic Freedom for Whom?, <http://academic-access.weebly.com/>

25 See, for example, Mearsheimer, John and Walt, Stephen 2007, The Israeli Lobby and US Foreign Policy, Farrar, Straus and Giroux, New York. 
certain hegemonic ideas and indifferent to the casual or concerted proscription of others? The UCU proposal is a principled and unsurprising response to a humanitarian and educational catastrophe. Is, then, the resultant barrage of counter-testimony consistent with how universities conduct themselves in their use of institutional autonomy to defend every exercise of academic freedom via contact with particular colleagues here and elsewhere? Exactly how is such elite speaking to be understood, and by whom? What weight can we give to such testimony, and why?

In the chronology of responses from 19 June to 13 July 2007 in my mini-archive, Canada's two leading universities, McGill and the University of Toronto, were first out of the gate, followed by less illustrious institutions from Nova Scotia to Vancouver Island. The tone of righteous protest being set by the most powerful members of an institutional hierarchy is strong in these statements, with excellence (at least in the sense most popular with educational leaders today) at the forefront. The impression of top-down leadership on core values is reinforced by the opening gambit of McGill's Principal and Vice-Chancellor, Heather Monroe-Blum, who appeals to the fundamental value of academic freedom...[and to] the values which form the foundation, and progressive evolution, of civil society'. She concludes on a note of cross-border, ivy-league solidarity (or cultural cringing) to supplement the allegiance to key academic and democratic ideas:

I join in solidarity with President Lee Bollinger of Columbia University [where of course Spivak is a long-time faculty member] and Chancellor Robert Birgenau of the University of California, Berkeley in support of unfettered interaction with Israeli scholars and institutions and in saying to those members of the UCU who would pursue this deplorable action: if you choose to isolate Israeli universities, you should add McGill to your boycott list. We will stand steadfast against those who seek to undermine academic freedom.

Dr Monroe-Blum speaks (over-)confidently on behalf of her entire institution, seeks legitimacy by association with presidential peers in the United States, strikes a bring-it-on note made notorious by a president even more powerful than she is and ends by reiterating her 'own' and other right-thinking academic communities' resolve to defend a noble tradition against a generalised threat from those who neither share nor wish to perpetuate 'our' values. Alas, this is righteous posturing not rigorous intellectual work. You can just imagine how the threat of a McGill boycott would strike terror into the hearts of British academics! Then there is her absolute silence on the matter of academic freedom for Palestinians, or about the public statement less than a month earlier by six of Dr Monroe-Blum's fellow presidents in Palestinian institutions about the grievous plight of their faculty and students. This presidential tribune 
follows a quasi-Huntingtonian script about the clash of civilisations and does so without ever naming the unspeakable other lent unwarranted succour by a few misguided British academics.

The University of Toronto's response is roughly twice as long as, and more nuanced than, McGill's. It is a personal message from President Naylor to the General Secretary of the UCU - an astute performance of the power of personal contact that the message wishes to promote. President Naylor explicitly connects the UCU's proposed boycott to similar actions aimed against apartheid in South Africa two decades ago. He claims an objection in principle that is consistent with his university's policy of contact rather than avoidance. Moreover, he buttresses this claim with a valid (but arguably exaggerated) claim for the solidarity of Israeli academics with their Palestinian colleagues and a (definitely exaggerated) claim on behalf of 'professors and university teachers world-wide'. Having objected 'strenuously' earlier in his statement to 'boycotts as broad-brush politicization of academic discourse', Dr Naylor then insouciantly politicises his own discourse broad brush, re-characterising scholarship and teaching 'worldwide' as 'the global academic enterprise', part of a larger 'human enterprise'. The term 'enterprise' is, however, currently a loaded one in Canadian debates about the commodification of knowledge and the casualisation of teaching within the increasingly corporate university, where only the academic comprador and entrepreneur seem truly welcome. Indeed, one might argue that free-market fundamentalism hides here within talk of academic fundamentals (along with a silently demonised Islamic fundamentalism), with free trade underlying and justifying academic freedom while corporate enterprises discreetly call the shots.

Such an interpretation is especially appealing in the case of the University of Toronto, 'home' to two of the most notorious recent cases involving institutional violations of academic freedom for fear of offending corporate donors - the cases involving Nancy Olivieri and David Healy. ${ }^{26}$ So, when its president testifies on behalf of the University of Toronto, shuttling between the poles of the personal and the universal as he does so, his speech is subverted by smugness and the public record. The dominant cannot find a voice or tense in which to speak, as it desires to do. No single voice can profess to speak for any academic community without resorting to amnesia while endeavouring to silence other voices that will inevitably stray 'off message', reclaiming from subaltern silence for complexity and critique a proposal portrayed unilaterally by academic leaders as self-evidently abhorrent.

26 See, respectively, Thomson, Jon, Baird, Patricia and Downie, Jocelyn 2001, Report of the Committee of Inquiry on the Case Involving Dr Nancy Olivieri, the Hospital for Sick Children, and Apotex Inc., CAUT, Ottawa;and Charlton, Bruce n.d., 'Drug money and academic freedom', Pharmapolitics, <http://www. pharmapolitics.com> 
Other administrators take their cues rapidly from Monroe-Blum and Naylor, responding more succinctly but covering much of the same ground. These statements generally attend to their institutional brand, whereas only two of the 24 examples (those from Toronto and Victoria) mention the statement by Palestinian university presidents - or mention Palestinians at all. Here is a case of wilful bias or culpable ignorance on behalf of leaders who claim global antennae and connections but a convenient aloofness too. Here, perhaps, is disdain that dare not speak its name. In these testimonies from the top there is no linking of the Shoah and al-Naqba. The plight of Palestinian academicsapparently unworthy of a flood of testimony on its own - is lost within a larger lip-service to generic freedoms in universities across the world. The subaltern institutions of the West Bank and Gaza have spoken, but with very uneven results. Moreover, North America appears especially impervious to such speech, at least at the institutional level, while pre-emption and erasure do their lethal work within the eager emission of outrage in both of Canada's official languages in the name of publicly funded institutions.

Of course, opposition to those who increasingly thought of themselves as CEOs speaking for everyone in the institutions they led was not long in coming - from faculty and students who could not be treated openly as subalterns without threatening the university brand. The proposed boycott remains a complicated and unfinished story, but for my purposes here it must suffice to note how some of those who sprang to the aid of academic freedom when they thought it threatened by the UCU have handled the exercise of that freedom on their own campuses. Consider, for instance, the controversy surrounding Israeli Apartheid Week (IAW), which has occurred in the first week in March every year since 2005 in Canada. As its name indicates, IAW is an explicit attempt to counter mainstream media coverage and a conservative government's arguable bias in favour of Israel. Supporters of IAW would seem to have a point when Canada's Minister of Citizenship, Immigration and Multiculturalism was reported thus in Haaretz while on a recent visit to Israel: 'I very acutely understand the nature of the new anti-Semitism, and I think it's even more dangerous than the old European anti-Semitism. ${ }^{27}$ What Minister Kenney is responding to in a broad-brush way is what he sees as a 'coalition of the far left in the West with extreme currents of jihadi Islam that seek the destruction of the Jewish nation'. Remember this minister's key portfolio within a poster democracy and then ask yourself about his reading of history. But of course Kenney is a member of the cabinet of Stephen Harper, admirer and plagiarist of John Howard, the same Harper who declared the Israeli action in southern Lebanon in 2006 to be 'measured' and links his government's foreign policy to a domestic stance of being 'tough on crime'. And another member of this federal cabinet, Gary

27 Ahren, Raphael 2009, 'Canada minister blasts "dangerous” leftist-Islamist anti-Semitism', Haaretz.com, 25 May 2009, p. 1, <http://www.haaretz.com/hasen/spages/1087973.html> 
Goodyear, recently asked the Social Sciences and Humanities Research Council of Canada (part of his ministerial portfolio) to review the funding it granted through its independent peer review process to organisers of an international conference promoted jointly by York and Queen's Universities on the theme of 'Israel/Palestine: Mapping models of statehood and paths to peace'. ${ }^{28}$

Among the figures speaking out pre-emptively against the proposed boycott of Israeli universities were the presidents of York, McMaster and Carleton Universities. At York, which has a rich history of internal and often rancorous debate, the president invoked 'the autonomy of universities' as the ground on which to deplore the proposed boycott. Institutional autonomy, however, functions increasingly in Canada as a pretext for the violation rather than the support of academic freedom for faculty and students. The York administration reacted to this year's organisers of IAW's programming by 'suspending the clubstatus for thirty days', fining them $\$ 1250$ for staging a preliminary rally on 12 February 2009 and demanding that they issue a "letter of apology" to the York community'. The rally was deemed offensive because it bore witness noisily and because of the size and substance of some of the banners on display. ${ }^{29} \mathrm{My}$ apparently inflammatory phrase, 'the semiotic stockade', gains new meaning from such censoring and from analogous actions at McMaster, where the very expression 'Israeli apartheid' was first banned by the Director of Human Resources and then permitted-but only in restricted font size and small lettering on banners. ${ }^{30}$ Orwell wert thou living at this hour! The contradictions continue to proliferate as the right to speak for, or as, the institution is asserted from above and contested from below. At York, the president declared that institutional autonomy meant universities were not and never should be 'an arm of their national government' and that 'the idea that individual universities should operate some kind of foreign policy is anathema to everything that, as academics, we stand for'. ${ }^{31}$ Yet those 'individual universities' seem through their presidents to have abandoned their individuality for a generic response almost indistinguishable in its self-righteous one-sidedness from the Canadian Government's position.

Can the institution speak? It cannot speak qua institution, but it can be misspoken for-in monologic forms that seek to re-corral academics as Bourdieu's

28 McIlroy, Anne 2009, 'Goodyear questions Mideast forum funds. Science Minister draws ire of academics for intervening on controversial conference', The Globe and Mail,10 June 2009, p. A5.

29 'Students against Israeli apartheid fight York University censorship', News and commentary on the Middle East, Arabist.com, posted 27 February 2009.

30 Solidarity for Palestinian Human Rights (SPHR) 2008, A Public Forum: Rights and responsibilities in political discussion on campus. Who speaks for McMaster?, 15 February 2008, <sphr.mcmaster@gmail.com> 31 YorkU, President's statement on the autonomy of universities, <http://www.yorku.ca/presidnt/news/ autonomy \%20of\%20universities.html> 
'dominated fraction' of a dominant class $^{32}$ via severe internal policing and self-censorship. So the answer to the question is no/yes in a domain of elite as well as subaltern activity. I hope that the question 'Can the institution speak?' will enjoy a little of the longevity and impact of Spivak's question, because the power to provoke is one we need to retain and use often in the current convergence of hegemony and homogeny, the yearning after total information awareness and its panoptic campus satellites, the Argus Project ${ }^{33}$ and Minerva Consortia led by the former president of Texas A \& M University and Bush and Obama's Secretary of Defence, Robert M. Gates, ${ }^{34}$ in the world's most powerful national-security state.

Insofar as universities are considered beacons of democracy in democratic societies, or as canaries in the mineshafts of freedom, they are especially revelatory of the enabling and limitation of power sharing, and the need to promote internal activism and vocal intervention on the part of the 'non-selfabdicating intellectual'. To this end, research centres, disciplinary departments, schools, faculty associations (unionised and not) and student organisations need to recognise and act on the discursive and justice implications of their 'own' power structures and individual and collective distributions of elite and subaltern status. In this way, academic institutions can disrupt the fraudulent pretensions to unity and representativeness that prevail inside and outside their notional borders. And that can in turn lead to the transformation of the academy's semiotic stockade into an 'information commons' in more than an information technology form bearing a corporate logo, or even into a 'knowledge mobilisation' commons with activism 'of the intellect, optimism of the will' as its modus operandi. 'The university' need not be merely a hotbed of cold feet, an ivory or irony tower or a corporate multiversity; it can also be an open-access multi-contrarian haven for optimally unencumbered inquiry and exchange, but only then will it be a safe place for performing and eliciting testimony: alma mater testimonia. In such an exercise of capacity without triumphalism, while valuing difference rather than managing diversity, perhaps scholars can make their gifts and privileges work more effectively for the rights of those called selectively, more or less coercively, and always belatedly, to speak beyond and against subalternity - to speak about the invasive injustices that have made them in part who they are and how they are.

32 See, for example, Swartz, David 1997, Culture and Power: The sociology of Pierre Bourdieu, University of Chicago Press, Chicago, p. 223.

33 National Association of Scholars, Argus Project, <http://www.nas./org/pol/PressReleases.cfm>

34 See Jaschik, Scott 2008, A Pentagon Olive Branch to Academe, <http://insidehighered.com/ news $/ 2008 / 04 / 16 /$ minerva $>$ 